\title{
Article
}

\section{The Chinese Position as a Global Player in International Comparison with the WTO Members: Efficiency Analysis and 4IR*}

\author{
Michaela Staníčková $^{* *} \&$ Lenka Fojtíková****
}

During the last quarter-century, globalisation processes affected changes in the world economy in the form of intensifying competition in the international and internal markets. The result is the creation of a global marketplace that is mostly indifferent to national borders and governmental influences. This development has generated widespread interest in competitiveness. Competitiveness affects international relations, especially nowadays, given the changing position of the global leaders and the growth of new economic powers such as China. China has come a long way and has the opportunity to be a global leader in several required fields that will be the cornerstones of global growth in the next decades. Led by China, emerging economies are increasing their share in the worldwide economy and intensifying competition in nearly all sectors. It creates new threats and challenges for players in the global economy, and growing competitiveness must be efficient. The article evaluates the Chinese competitiveness in comparison with the World Trade Organization

* The article was supported by the Czech Science Agency project No. 17-22426S: Law Aspects of China's Incorporation into the Global Trade System. All the websites cited in this article was last visited on February 10, 2020.

** Corresponding author. Professor of Department of European Integration at the Faculty of Economics, VŠB-Technical University of Ostrava. doc. Ing. Ph.D. (VŠB-TUO). ORCID: http://orcid. org/0000-0001-6210-2377. The author may be contacted: michaela.stanickova@vsb.cz/Address: 17. listopadu 2172/15, 708 o0 Ostrava-Poruba, Czech Republic (EU).

*** Professor of Department of European Integration at the Faculty of Economics, VŠB-Technical University of Ostrava. doc. Ing. Ph.D. (VŠB-TUO). ORCID: http://orcid.org/0000-0002-1544-2421. Address: VŠB-Technical University of Ostrava, 17. listopadu 2172/15, 70800 Ostrava-Poruba, Czech Republic (EU). 
members by the Data Envelopment Analysis in the pre-in-post crisis period and considering the Fourth Industrial Revolution shifting humanity into a new phase.

Keywords: 4IR, China, Competitiveness, DEA, Economic Development, Efficiency, Globalisation, Super-Efficiency, WEF, WTO

\section{INTRODUCTION}

It is globally accepted that the stage of economic development is not uniform and balanced across territories. On the contrary, it significantly and ambiguously differs. Human actions are related to economic growth and influenced by the level of territorial development, the ways and means of measurement, as well as evaluation of the conditions of national development. It is essential in the determination and orientation of national socio-economic policies. The prosperity of a country depends more and more on the international competitiveness of its firms and industries. Even though a country may be competitive, if its economic, social and environmental factor suffers too much, the economy will face significant difficulties and vice versa. Therefore, governments need an integrated approach to govern the country. Analysis in respectively of the public sector is the starting point for studying the role of performance regarding the economic governance of resource utilisation by public management for achieving the short-term and medium-term goals of economic recovery and sustainable way of countries' development. ${ }^{1}$ Increasing performance is the only viable way of improving living standards in the long-term. Statistical evidence helps the policymakers to understand the routes of economic performance growth. In order to get empirical applications for economic policy, the article employs the Data Envelopment Analysis ("DEA") approach.

The article aims to propose a DEA application to evaluate efficiency changes and to analyse level of productivity depending on each country's stage of development. DEA is applied in the form of output-oriented Banker-CharnesCooper model of efficiency with variable returns to scale ("OO BCC VRS") with the equal number of inputs and outputs (6 inputs and 6 outputs). Subsequently, output-oriented Andersen-Petersen model of super-efficiency with variable returns to scale ("OO APM VRS") is applied for ranking. The calculation verifies the sample of 137 World Trade Organization ("WTO") members in the reference 
period 2007-2018 (including all the years within this range, i.e., the pre-in-post crisis). Variables of inputs and outputs present the factors of competitiveness based on Global Competitiveness Index ("GCI"), which is part of the Global Competitiveness Reports ("GCR”) published by the World Economic Forum ("WEF") every year. Special attention is dedicated to the Chinese position within the whole sample (137 WTO members), and within countries belonging to the $2^{\text {nd }}$ stage of development (45 countries). In recent years, China has also been very active in the global economy. In 2001, China's accession to the WTO was widely regarded as a significant milestone, especially from two points of view; firstly for the Chinese economy; and secondly, the multilateral world trading system influencing global economic growth, international trade, transparency of trade policy, regional trade arrangements, foreign direct investment, banking sector liberalization, exchange rate reform, agricultural trade and energy demand. What are the implications of China's incorporation into the world market as well as global trade for the competitiveness of the other WTO members? The WTO competitiveness and the impacts on the Chinese economy will be evaluated. Another part of the evaluation of competitiveness is the recent technological revolution, i.e., the Fourth Industrial Revolution ("4IR") significantly changing the conception of competitiveness. Developments in the form of the impact of economic crises and the consequences of 4IR are redefining the pathways to prosperity with profound implications for policy-making. ${ }^{2}$

\section{LITERATURE REVIEW}

Globalisation generally refers to a process of broadening and deepening the interrelationships. The outcome is the global marketplace that is mostly indifferent to national borders and governmental influence. Since the 1960s, the globalisation have altered the production, export and employment structure of the world economy, but many barriers to full integration still remains. Rapid technological change, coupled with falls in barriers to international trade, have driven it. Also, other WTO agreements and regional treaties forced domestic markets to open up. China's accession to the WTO is a landmark event in China's economic reform and in the evolution of the international trading system. This accession also has a significant 
impact on all players in the world economy. China's leaders expect to leverage the increased foreign competition inherent in its WTO commitments to transform the country's inefficient, money-losing companies and hasten the development of a commercial credit culture in its banking system. This development and the wave of globalisation has generated widespread interest among the development and upgrading of macroeconomic competitiveness.

In recent years, the topics about measuring and evaluating competitiveness have enjoyed economic interest. Although there is no uniform definition and understanding of competitiveness, this concept not only remains one of the basic standards of performance evaluation, but is also seen as a reflection of the success of area in a broader comparison. The idea of competitiveness is distinguished at different levels - microeconomic, macroeconomic and regional - which differ from each other. ${ }^{3}$ The need for a theoretical definition of competitiveness at the macroeconomic level emerged with the development of the globalisation process in the world economy as a result of increased competition between countries. In order to understand what the competitiveness is in a national perspective, it is the best to look at the definition given by the President's Commission on Industrial Competitiveness: "Competitiveness is the degree to which a nation can, under free and fair market conditions, produce goods and services that meet the test of international markets while simultaneously maintaining or expanding the real incomes of its citizens." ${ }^{4}$ This is the most quoted definition in this area and defines competitiveness from a macro perspective. Many authors have also referred to this definition of competitiveness of nations. $^{5,6,7,8}$ The description points out that the ultimate goal of competitiveness is to maintain and increase the real income of its citizens, usually reflected in the standard of living of the country. From this perspective, the competitiveness of a nation is not an end but a means to an end; its ultimate goal is to increase the standard of living of a society under free and fair market conditions. It "refers to the country's ability to create, produce, distribute, and service products in international trade while earning rising returns on its resources." Arguably, national governments' principal goal is to establish an environment that fosters a high standard of living for its citizens by addressing health, safety, laws, and environmental issues. This goal can be achieved, in part, through effective management and allocation of resources for producing the highest attainable level of products. It becomes imperative that governments coordinate a comprehensive approach towards trade and investment incorporating 
a competition orientation. ${ }^{10}$ Many nations are very aware of the fact that internal growth depends upon their ability to sustain trade and attract foreign investment.

The concept of international competitiveness of nations makes sense only within a national economic context. Countries adopt economic and trade policies that directly affect the ability of enterprises and industries to engage in international trade and investment. Several studies have been devoted to the competitiveness of international trade. The authors focus either on one particular country and its foreign relations or discuss the situation of a specific union of countries concerning its environment, or the situation within. In his book, THE Competitive Advantage of Nations, M. Porter observes that two sets of indicators measure macroeconomic competitiveness: (1) the presence of substantial and sustained exports to a wide array of other nations; and/or (2) significant outbound foreign investment based on skills and assets created in the home country. ${ }^{11}$ Porter notes that the strength of their factor endowments determines the competitive advantage of nations; their demand conditions; the competitiveness of firm strategies, structures, and rivalries in significant industries; and the power and diversity of related and supporting industries. It should be emphasised that openness to global markets and the internationalisation of economies play an increasing role in competitiveness enhancement. ${ }^{12}$

\section{MethodS}

Efficiency measurement has been the challenge of many subjects which have the interest to improve their productivity. In 1957, Farrell investigated the question of how to measure efficiency and highlighted its relevance for economic policymakers. ${ }^{13}$ One of the reasons that all attempts to solve the problem have failed is the irrelevance in combining the measurement of multiple inputs into undesirable outputs. ${ }^{14}$ Since then, techniques to measure efficiency have become more frequent and therefore they improved.

\section{A. Conceptual Issue}

In recent years, the topics about measuring and evaluating competitiveness have enjoyed economic interest. Macroeconomic competitiveness is monitored by 
many institutions. Two well-known international institutes, i.e., the Institute for Management Development ("IMD") and World Economic Forum ("WEF") publish most reputable competitiveness reports. To compare a level of competitiveness of separated countries in the article, the authors use the database elaborated by WEF. The first reason for choosing the WEF approach is its long-term continuity and international recognition of stakeholders. Since 1979, WEF publishes the Global Competitiveness Report ("GCR") that produces the annual Global Competitiveness Index ("GCI") to rank national economies. GCR aims to serve as a neutral and objective tool for governments, the private sector, and civil society to work together on effective public-private collaboration to boost future prosperity. ${ }^{15} \mathrm{By}$ benchmarking each year's progress on different factors and institutions that matter for future growth, GCR keeps competitiveness on the public agenda, provides a focal point for the discussion of long-term competitiveness policies, and helps to hold stakeholders accountable. The ability to compare economies on a variety of indicators helps them to assess gaps and priority areas and to construct joint, public-private agendas to address them. However, do all countries have the same opportunities in terms of competitiveness? Countries face very different challenges and priorities as they move from resource-based to knowledge-based economies, which influence their competitive advantages and also disadvantages. Generally accepted is that the level of economic development is not uniform across territories; it differs as an economy develops. This process can be described as a sequence of stages, each with different characteristics: ${ }^{16}$

- factor-driven stage: competitive advantage is based exclusively on endowments of labour and natural resources;

- investment-driven stage: efficiency in producing standard products and services becomes the dominant source of competitive advantage;

- innovation-driven stage: the ability to provide innovative products and services at the global technology frontier using the most advanced methods becomes the authoritative source of competitive advantage.

Seeing economic development as a sequential process of building not just macroeconomic stability but also interdependent factors such as quality of governance, the societal capacity to advance its technological capability, more advanced modes of competition, and evolving forms of firm organisational structure, helps to expose 
significant potential pitfalls in economic policy orientated on competitiveness. ${ }^{17}$

Nowadays, competitiveness is monitored characteristic of national economies, which is increasingly appearing in evaluating their performance and prosperity, welfare and living standards. Competitiveness is one of the fundamental criteria for evaluating economic performance and reflects the success of the area. Territories need highly performing units to meet their goals, to deliver the products and services they specialised in, and finally to achieve competitive advantage. Low performance and not making the purposes might be experienced as dissatisfying or even as a failure. Comparative analysis of performance in public sector is thus starting point for studying the role of efficiency/productivity and effectiveness, i.e., two aspects of performance regarding economic governance of resources utilization by public management for achieving objectives of economic recovery and sustainable development of national economies. ${ }^{18}$ Increasing productivity is generally considered to be the only viable way of improving living standards in the long term. Productivity is thus a central issue in analyses of economic growth, effects of fiscal plans, pricing of capital assets, level of investments, technology changes and production technology, etc. Based on Porter, competitiveness is usually linked to productivity. ${ }^{19}$ Figure 1 illustrates the conceptual framework of efficiency (inputsoutputs) and effectiveness (outputs-outcomes). Efficiency can be achieved under conditions of maximising results of action about resources used, and it is calculated by comparing effects (outputs) obtained in their efforts (inputs). Effectiveness is more challenging to assess than efficiency since the outcome is influenced by political choice and often linked to welfare or growth objectives. Drucker stated that there is no efficiency without effectiveness because it is more important to do well what you have proposed than to do well something else that was not necessarily a concern. ${ }^{20}$ Based on the Institute for Management and Development, competitiveness is a field of economic knowledge analyses facts and policies that shape the ability of a nation to create and maintain an environment that sustains more value creation for its enterprises and more prosperity for its people. ${ }^{21}$ Competitiveness measures how a nation manages the totality of its resources and competencies to increase the prosperity of its people. ${ }^{22}$

Three key topics (competitiveness - productivity - stage of development) are essential for the article concept (Figure 1): 1) the relationship between concepts of competitiveness - productivity; 2) the relationship between theories of 
competitiveness and stage of development; 3) the relationship between WEF's approach to competitiveness evaluation and stage of development concept; 4) the relationship between WEF's approach to competitiveness evaluation and understanding of competitiveness through productivity; and 5) the relationship between quantitative method and its suitability to productivity evaluation.

\section{Figure 1: Connectivity among Concepts}

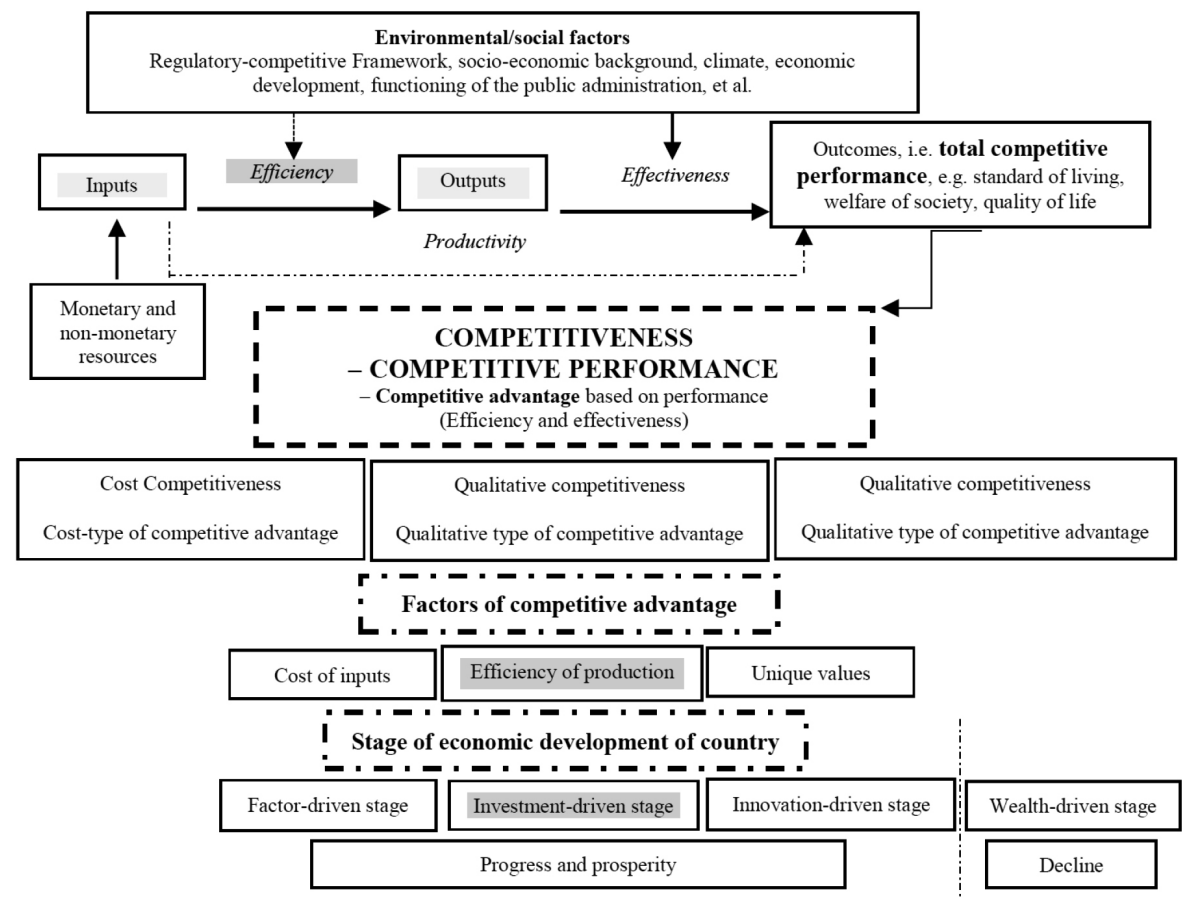

Source: Compiled by the authors based on Mihaiu \& Opreana \& Cristescu, supra note 1.

\section{B. Methodological Issue}

Performance management is one of the primary sources of sustainable organisational efficiency, and a systematic understanding of the factors that affect productivity is fundamental. The primary problem in creating an evaluation of any system is establishing clear performance standards and priorities at the beginning of the performance cycle. The early research work on this problem focused on separate measures of productivity. These inadequate approaches included forming the 
average productivity for a single input (ignoring all the other inputs) and constructing an efficiency index in which a weighted average of the inputs is compared with the outputs. Responding to these inadequacies of separate indices, Farrell proposed an approach dealing more adequately with the problem. ${ }^{23}$ Farrell had already investigated the question of how to measure efficiency and highlighted its relevance for policymakers. Twenty years after Farrell's model, and building on those ideas, Charnes, Cooper and Rhodes, responding to the need for satisfactory procedures to assess the relative efficiencies of multi-input/multi-output production units, introduced the DEA methodology. ${ }^{24}$ The approach is based on the simple model of Farrell for measuring the efficiency of units with one input and one output initially expanded in 1978 by Charnes, Cooper, and Rhodes ("CCR" model) assuming constant returns to scale ("CRS"), and later modified in 1984 by Banker, Charnes and Cooper ("BCC" model), in the form of BCC model assuming variable returns to scale ("VRS"). ${ }^{25}$ DEA also includes advanced additive models, such as Slacks-Based Model ("SBM") introduced by Tone, ${ }^{26}$ Free Disposal Hull ("FDH") and Free Replicability Hull ("FRH") models first formulated by Deprins, Simar and Tulkens. ${ }^{27}$

DEA is approach for providing a relative efficiency assessment of the performance of a set of peer entities called decision-making units ("DMUs") converting multiple inputs into multiple outputs. The definition of DMU is generic and flexible. DEA is convenient for determining the efficiency of DMUs that are mutually comparable using the same inputs for producing the same outputs but with different efficiencies. Thus, DEA may categorise DMUs into two mutually exclusive sets: efficient and inefficient. Determining whether DMU is efficient from the observed data is equivalent to testing whether the DMU is on the frontier of the production possibility set. DMU is efficient if the observed data correspond to questioning whether the DMU is on the imaginary production possibility frontier. ${ }^{28}$ All other DMUs are inefficient. The best-practice units are used as a reference for evaluation of the other group units. The efficiency score of DMU is defined by the formula (1): ${ }^{29}$

$$
\text { efficiency }=\frac{\text { weighted sum of outputs }}{\text { weighted sum of inputs }} \text {. }
$$

Various types of DEA models can be used, depending upon the problem at hand. 
Used DEA model can be distinguished by the scale and orientation of the model. If one cannot assume that economies of scale change, then a variable returns to scale ("VRS") type of DEA model, the one selected here, is an appropriate choice (as opposed to constant returns to scale, ("CRS" model). Furthermore, if to achieve better efficiency, governments' priorities are to adjust their outputs (before inputs), then an output-oriented ("OO") DEA model, rather than an input-oriented ("IO") model, is appropriate. For calculations of macroeconomic efficiency, outputoriented BCC model with VRS is used in the article. Computing the efficiency scores explains the following model (2): ${ }^{30}$

$$
\min \mathrm{g}=\varnothing_{q}+\varepsilon\left(\mathrm{e}^{\mathrm{T}} \mathrm{s}^{+}+\mathrm{e}^{\mathrm{T}} \mathrm{s}^{-}\right)
$$

subject to

$$
\begin{gathered}
\mathrm{X} \lambda+\mathrm{s}^{-}=\mathrm{x}_{q}, \\
\mathrm{Y} \lambda-\mathrm{s}^{+}=\emptyset_{q} \mathrm{y}_{q}, \\
\mathrm{e}^{\mathrm{T}} \lambda=1, \\
\lambda, \mathrm{s}^{+}, \mathrm{s}^{-} \geq 0,
\end{gathered}
$$

where $g$ is the coefficient of efficiency of unit $U_{q} ; \varnothing_{q}$ is radial variable indicates the required rate of increase of output; is infinitesimal constant; $\mathrm{e}^{\mathrm{T}} \lambda$ is convexity condition; $\mathrm{s}^{+}$, and $\mathrm{s}^{-}$are vectors of slack variables for inputs and outputs; $\lambda$ represent the vector of weights assigned to individual units; $x_{q}$ means vector of input of unit $U_{q} ; y_{q}$ means vector of output of unit $U_{q} ; \mathrm{X}$ is the input matrix; Y is the output matrix. In the BCC model aimed at outputs, the coefficient of efficient DMU equals 1, but the coefficient of inefficient DMU is greater than 1 .

In the BCC model, the coefficients of efficient DMUs equal to 1. Based on the chosen model and the relationship between the number of units and the number of inputs and outputs, several efficient units can be relatively large. Due to the possibility of efficient units' classification, Andersen-Petersen's model (“APM") of super efficiency is used. Following a variable return to scale ("VRS") model is an output-oriented dual version of APM (3): ${ }^{31}$ 


$$
\max g=\varnothing_{q}+\varepsilon\left(\mathrm{e}^{\mathrm{T}} \mathrm{s}_{i}^{+}+\mathrm{e}^{\mathrm{T}} \mathrm{s}_{i}^{-}\right)
$$

subject to

$$
\begin{gathered}
\sum_{j=1}^{n} x_{i j} \lambda_{j}+\mathrm{s}_{i}^{-}=x_{i q}, \\
\sum_{j=1}^{n} y_{k j} \lambda_{j}-\mathrm{s}_{i}^{+}=\varnothing_{q} y_{k q}, \\
\lambda_{q}=0, \\
\lambda_{j}, \mathrm{~s}_{k}^{+}, \mathrm{s}_{i}^{-} \geq 0, \\
j=1,2, \ldots, n, j \neq q ; k=1,2, \ldots, r ; i=1,2, \ldots, m .
\end{gathered}
$$

where $x_{i j}$ and $y_{k j}$ are $i$-th inputs and $k$-th outputs of $D M U_{j} ; \varnothing_{q}$ is efficiency index (intensity factor) of observed $D M U_{q} ; \lambda_{j}$ is the dual weight which shows $\mathrm{DMU}_{\mathrm{j}}$ significance in the definition of an input-output mix of the hypothetical composite unit, $D M U_{q}$ directly comparing with. The coefficient of inefficient units is identical to model (2), i.e., $\left(\varnothing_{q}>1\right)$; for units identified as efficient in the model (2), provides OO APM (3) the coefficient of super-efficiency lower than 1, i.e., $\varnothing_{q} \leq 1$. Table 1 displays the characteristics of OO BCC-APM VRS.

Table 1: Characteristics of Efficiency and Super-Efficiency Models

\begin{tabular}{c|c|c}
\hline DEA Model & \multicolumn{2}{|c}{ Score of Coefficient } \\
\hline OO BCC VRS - efficiency model & $=1$ (efficient DMU) & $>1$ (inefficient DMU) \\
\hline OO APM VRS - super-efficiency model & $<1$ (efficient DMU) & $>1$ (inefficient DMU) \\
\hline
\end{tabular}

Source: Compiled by the author based on COOPER et al., supra note 14 .

Suppose there are $n$ DMUs which consume $m$ inputs to produce $s$ outputs. If a performance measure (input/output) is added or deleted from consideration, it will influence the relative efficiencies. Empirically, when the number of performance measures is high in comparison with the number of DMUs, then most of the 
DMUs are evaluated efficiently. Hence, the obtained results are not reliable. There is a rule of thumb suggested by Cooper, Li, Seiford and Zhu which expresses the relation between the number of DMUs and the number of performance measures sufficient for DEA to be used, as follows (4), in simplification (5): ${ }^{32}$

$$
\begin{gathered}
n \geq \max \{m \times s, 3(m+s)\}, \\
n \geq 3(m+s) .
\end{gathered}
$$

The following section examines a real data set involving 137 WTO members (for each of 6 inputs and 6 outputs) to validate the proposed approach. In the article, the rule of thumb meets all the cases of DEA empirical analysis - classification of countries into stages of development based on the WEF approach, i.e.,.: ${ }^{33}$

- for the sample of 137 WTO members: $137 \geq 3(6+6), 137 \geq 3$ (12), $137 \geq 36$;

- for countries within the $2^{\text {nd }}$ stage of development including China, i.e., 45 WTO members: $45 \geq 3(6+6), 45 \geq 3$ (12), $45 \geq 6$.

\section{Results AND Discussions}

Since its inception, DEA has become essential and widely used means in many types of research and analysis with a different sectoral and territorial focus including applications to the EU countries. ${ }^{34,35}$ Such studies have a similar context and research question focusing on the fundamentals of competitiveness and advantages concerning the evaluated territory.

\section{A. Analysis Background}

In the article, research is interested in determining the DEA result of each country by comparing its productivity with others in the group of the WTO members, i.e., territorial aspects of empirical analysis. The WTO consists of 164 members since July 29, 2016, but not all of these countries are included due to data nonavailability concerning selected approach for a database of indicators - WEF. ${ }^{36}$ The territorial aspect of analysis is thus dedicated to the WTO members (137 
countries), as well as to countries within the $2^{\text {nd }}$ stage of development, including China (45 countries). The country's affiliation to a particular stage of development determines its GDP per capita and the share of exports represented by raw materials. ${ }^{37}$ Although all of the GCI pillars will matter to a certain extent for all economies, it is clear that they affect various economies in different ways. ${ }^{38}$ Classification of countries is as follows: ${ }^{39}$

- factor-driven stage (56 countries): GDP per capita (USD) threshold $<2.999$;

- efficiency-driven stage (45 countries): GDP per capita (USD) threshold 3.00017.000 , i.e., countries within the $2^{\text {nd }}$ stage of development is the subject of analysis;

- innovation-driven stage (36 countries): GDP per capita (USD) threshold $>17.000$.

The second reason for choosing WEF is its approach to perceiving competitiveness and suitability in terms of the used quantitative method in line with the used database. Indicators represent twelve GCI pillars, which are crucial for the evaluation of productivity among the WTO members by DEA approach. GCI pillars represent both sides of the required indicators, i.e., input and output size. Indicators come from WEF's database published within GCR in period 2007-2018. ${ }^{40,41}$ In GCR, WEF defines competitiveness as the set of institutions, policies, and factors that determine the level of productivity of a country. Level of productivity, in turn, sets the level of prosperity that can be reached by an economy. This open-mindedness is captured within the GCI by including a weighted average of many different components, each measuring a different aspect of competitiveness. The components are grouped into 12 categories, the pillars of competitiveness, which are not independent; they tend to reinforce each other; and a weakness in one area often hurts the others. GCI pillars may be grouped according to the different dimensions (input versus output aspects) of competitiveness they describe. The terms 'inputs' and 'output' are meant to classify pillars into those which represent driving forces of competitiveness, also in terms of long-term potentiality, and those which are direct or indirect outputs of a competitive society and economy. It is not easy to decide on which GCI pillars are the economic drivers in terms of competitiveness (inputs) and which are the results of activities in the economy (outputs). For this purpose, the authors use the appropriate classification based on the EU Regional Competitiveness Index (RCI), created partly in line with GCI construction (Table 2). ${ }^{42}$

Input indicators ("II") represent pillars of Institutions ("II1"), Infrastructure 
("II2"), Macroeconomic environment ("II3"), Health and primary education ("II4"), Higher education and training ("II5"), and Technological readiness ("II6"). Output indicators ("OI") represent pillars of Goods market efficiency ("OI1"), Labour market efficiency (“OI2"), Financial market development (“OI3”), Market size ("OI4"), Business sophistication ("OI5"), and Innovation ("OI6"). Importance of each of the pillars for the issue of competitiveness describe following summary: ${ }^{43}$

- II1 Institutions: The institutional environment of a country depends on the efficiency and the behaviour of both public and private stakeholders. The legal and administrative framework within which individuals, firms, and governments interact determines the quality of the public institutions of a country and has a strong bearing on competitiveness and growth.

- II2 Infrastructure: Effective modes of transport enable entrepreneurs to get their goods and services to market in a secure and timely manner and facilitate the movement of workers to the most suitable jobs. Economies also depend on electricity supplies so that businesses and factories can work unimpeded. Solid and extensive telecommunications network allows for a rapid and free flow of information, which increases overall economic efficiency.

- II3 Macroeconomic environment: The stability of the macroeconomic environment is important for business and, therefore, is significant for the overall competitiveness of a country. Although it is certainly true that macroeconomic stability alone cannot increase the productivity of a nation, it is also recognized that macroeconomic disarray harms the economy.

- II4 Health and primary education: A healthy workforce is vital to a country's competitiveness and productivity. Workers who are ill cannot function to their potential and will be less productive. Basic education increases the efficiency of each individual worker.

- II5 Higher education and training: Quality higher education and training is crucial for economies that want to move up the value chain beyond simple production processes and products. Today's globalizing economy requires countries to nurture pools of well-educated workers who are able to perform complex tasks and adapt rapidly to their changing environment and the evolving needs of the production system.

- II6 Technological readiness: The agility with which an economy adopts existing technologies to enhance the productivity of its industries, with specific emphasis on its capacity to fully leverage information and communication technologies in daily activities and production processes for increased efficiency and enabling innovation for competitiveness. 
- OI1 Goods market efficiency: Countries with efficient goods markets are well positioned to produce the right mix of products and services given their particular supply-and-demand conditions, as well as to ensure that these goods can be most effectively traded in the economy. Healthy market competition is important in driving market efficiency, and thus business productivity, by ensuring that the most efficient firms, producing goods demanded by the market, are those that thrive.

- OI2 Labour market efficiency: The efficiency and flexibility of the labour market are critical for ensuring that workers are allocated to their most effective use in the economy and provided with incentives to give their best effort in their jobs. Labour markets must therefore have the flexibility to shift workers from one economic activity to another rapidly and at low cost, and to allow for wage fluctuations without much social disruption. Efficient labour markets must also ensure clear strong incentives for employees and promote meritocracy at the workplace, and they must provide equity in the business environment between women and men.

- OI3 Financial market development: An efficient financial sector allocates the resources saved by a nation's population, as well as those entering the economy from abroad, to the entrepreneurial or investment projects with the highest expected rates of return rather than to the politically connected. Economies require sophisticated financial markets that can make capital available for private-sector investment from such sources as loans from a sound banking sector, well-regulated securities exchanges, venture capital, and other financial products.

- OI4 Market size: The size of the market affects productivity since large markets allow firms to exploit economies of scale. Traditionally, the markets available to firms have been constrained by national borders. In the era of globalization, international markets have become a substitute for domestic markets, especially for small countries. Thus exports can be thought of as a substitute for domestic demand in determining the size of the market for the firms of a country.

- OI5 Business sophistication: Business sophistication concerns two elements that are intricately linked: the quality of a country's overall business networks and the quality of individual firms' operations and strategies. The quality of a country's business networks and supporting industries, as measured by the quantity and quality of local suppliers and the extent of their interaction.

- OI6 Innovation: Innovation is particularly important for economies as they approach the frontiers of knowledge, and the possibility of generating more value by merely integrating and adapting exogenous technologies tends to disappear. In these economies, firms must design and develop cutting-edge products and processes to maintain a competitive edge and move toward even higher value-added activities.

Although all of the GCI pillars matter to a certain extent for all economies, it 
is clear that they affect various economies in different ways what confirms the importance of application of different stage of the development concept.

The reference period 2007-2018 includes years of growth dynamics and economic downturn and stagnation, effects of the economic crisis and subsequent recession can be considered as the other milestones (pre-in-post crises years). Time-series is set concerning the GCI concept - including convenient input-output indicators to DEA - since data before the GCR 2006 edition are not available due to the changes in the GCI methodology. DEA calculates year-on-year efficiency scores in all years of period 2007-2018, as well as periodical changes for years of pre-crisis period (2007-2010), crises period (2011-2014) and the post-crisis period (2015-2018), as shown in Table 2.

Table 2: Background of DEA Empirical Analysis

\begin{tabular}{|c|c|c|c|c|}
\hline \multicolumn{2}{|l|}{ GCI pillars - Inputs (II 1-6) } & DMUs & \multicolumn{2}{|c|}{ GCI pillars - Outputs (OI 1-6) } \\
\hline 1. Institutions & \multirow{6}{*}{\multicolumn{2}{|c|}{$\begin{array}{l}137 \text { WTO } \\
\text { members; } \\
2^{\text {nd }} \text { stage of } \\
\text { development } \\
\text { (45 countries) }\end{array}$}} & \multicolumn{2}{|c|}{ 1. Goods market efficiency } \\
\hline 2. Infrastructure & & & \multicolumn{2}{|c|}{ 2. Labour market efficiency } \\
\hline 3. Macroeconomic environme & & & \multicolumn{2}{|c|}{ 3. Financial market development } \\
\hline 4. Health and primary educati & & & \multicolumn{2}{|r|}{ 4. Market size } \\
\hline 5. Higher education and traini & & & \multicolumn{2}{|c|}{ 5. Business sophistication } \\
\hline 6. Technological readiness & & & \multicolumn{2}{|r|}{ 6. Innovation } \\
\hline \multicolumn{5}{|c|}{ Time-series } \\
\hline GCI editions & \multicolumn{3}{|c|}{ Annual and periodical changes } & Total period change \\
\hline $\begin{array}{c}11 \text { GCR editions } \\
(2007-2008, \ldots, 2017-2018), \\
\text { GCR } 2018\end{array}$ & \multicolumn{3}{|c|}{$\begin{array}{l}2007,2008,2009,2010, \\
2011,2012,2013,2014, \\
2015,2016,2017,2018 ; \\
2007-2010,2011-2014, \\
\text { 2015-2018 }\end{array}$} & $\begin{array}{c}\text { Total changes across years } \\
\text { in period 2007-2018; } \\
\text { GCR } 2018\end{array}$ \\
\hline
\end{tabular}

Source: Compiled by the authors based on WEF, Reports (2018b).

Follow-up part of the evaluation is the 4IR that significantly changes the competitiveness. The changing to nature of economic competitiveness in a world that is becoming increasingly transformed by new, digital technologies is creating a 
new set of challenges for governments and businesses, which collectively run the risk of hurting future growth and productivity. To make evaluation thematically relevant, the WEF approach is also used in assessing competitiveness in the light of the technical revolution effect, i.e., the critical findings of WEF's Global Competitiveness Report 2018 in the form of GCI 4.0. - a new composite index for assessing the factors determining an economy's level of productivity - widely considered as the most critical determinant of long-term growth. ${ }^{44}$ At a time of escalating trade tensions and a backlash against globalisation, GCI 4.0 reveals the importance of openness for competitiveness. According to the report, which uses a brand new methodology to capture the dynamics of the global economy in 4IR fully, many of the factors that will have the most significant impact in driving competitiveness in the future have never been the focus of important policy decisions in the past. These include idea generation, entrepreneurial culture, openness, and agility. A key message from GCI 4.0 is the need for a broadbased approach to raising competitiveness - a strong performance in one area cannot make up for a weak performance in another. Competitiveness is neither a competition nor a zero-sum game. Instead, all countries can become more prosperous. With opportunities for economic leapfrogging, diffusion of innovative ideas across borders and new for the new forms of value creation, 4IR can level the playing field for all economies. But technology is not a silver bullet on its own. Countries must invest in people and institutions to deliver on the promise of technology. ${ }^{45}$

\section{B. Efficiency and Super-Efficiency Analysis}

Openness to trade, investment and even the movement of people is vital for prosperity, peace and individual freedom. And there have been few moments in history to reconfirm the role of trade as central to global growth, job creation and development. Today's economic circumstances are full of challenges, especially after the year 2007. The 2008 global financial crisis interrupted a period of sustained economic growth dating back to the 1960s. Since then, despite unorthodox monetary policy and fiscal stimulus packages, advanced economies have experienced prolonged comparatively sluggish growth. In emerging markets, the impact of the global financial crisis was lessened in part by interest rate differentials, with advanced economies fuelling capital inflows in the form of 
foreign direct investment, the commodity super-boom, and - related to this - the rapid growth of China. The growth of the Chinese economy has been tremendous. Only recently, emerging economies have advanced and begun to show signs of recovery. These threats and opportunities have also intensified competition in global markets, which, in turn, implies a greater need to be competitive to generate additional market opportunities and economic links in the presence of many more participants vying for the same space. China has the chance to be a global leader in several essential areas that will be the cornerstones of global growth in the next decades and this is also challenging for its biggest competitors. ${ }^{46}$

Despite this positive development after the economic crisis, leaders are facing significant predicaments when it comes to economic policy. Uneven distribution of the benefits of economic progress, generational differences, rising income inequality in advanced economies, and increasing environmental degradation have heightened the sense that the economic policies of past years have not served citizens or society well. Significant technological disruption and the new fault lines emerging in the global economic and political order add further uncertainty about the types of strategies that will make economies future-proof. Taken together, all of these factors are challenging decision-makers to find new approaches and strategies to advance economic progress. Emerging consensus is that economic growth once again needs to focus more on human well-being. Such human-centric economic development is multi-dimensional by nature - it is broad-based by benefitting the vast majority of people, environmentally sustainable, and equitable in terms of creating opportunities for all and not disadvantaging future generations. Competitiveness remains an essential contribution to the broader goal of humancentric economic progress by creating resources needed for increased well-being, including better education, health, security, and higher per capita income. ${ }^{47}$

Considering the increasing importance of economic growth in the society and presence in a competitive world, evaluation of the territorial performance has been remarkably considered, and various measures are brought up as a criterion in the assessment of national performance. Table 3 presents annual and periodical efficiency changes of OO BCC VRS and OO APM VRS for the whole sample of 137 evaluated countries gained in the form of averages based on efficiency scores for the entire reference period 2007-18. Table 3 presents results for countries within the $2^{\text {nd }}$ stage of development including China (45 countries) for annual and 
periodic efficiency changes of OO BCC VRS, and OO APM VRS gained in the form of averages based on efficiency scores. Level of efficiency measured by both models of efficiency and super-efficiency does not show extreme variability in the whole sample of evaluated across individual years as well as changes among three crises-periods.

Table 3: Results of OO BCC-APM VRS in 2007-2018

\begin{tabular}{|c|c|c|c|c|c|c|c|c|c|c|c|c|}
\hline \multirow{2}{*}{$\begin{array}{c}\text { WTO } \\
\text { Members }\end{array}$} & \multicolumn{12}{|c|}{ OO BCC VRS Model of Efficiency } \\
\hline & 2007 & 2008 & 2009 & 2010 & 2011 & 2012 & 2013 & 2014 & 2015 & 2016 & 2017 & 2018 \\
\hline \multirow{2}{*}{137 countries } & 1.033 & 1.024 & 1.024 & 1.023 & 1.023 & 1.023 & 1.027 & 1.030 & 1.028 & 1.026 & 1.032 & 1.029 \\
\hline & \multicolumn{4}{|c|}{1.026} & \multicolumn{4}{|c|}{1.026} & \multicolumn{4}{|c|}{1.029} \\
\hline \multirow{2}{*}{$\begin{array}{c}2^{\text {nd }} \text { stage } \\
(45 \text { countries })\end{array}$} & 1.019 & 1.016 & 1.011 & 1.009 & 1.012 & 1.008 & 1.011 & 1.012 & 1.015 & 1.015 & 1.010 & 1.013 \\
\hline & \multicolumn{4}{|c|}{1.014} & \multicolumn{4}{|c|}{1.011} & \multicolumn{4}{|c|}{1.013} \\
\hline \multirow{2}{*}{$\begin{array}{c}\text { WTO } \\
\text { Members }\end{array}$} & \multicolumn{12}{|c|}{ OO APM VRS Model of Super-Efficiency } \\
\hline & 2007 & 2008 & 2009 & 2010 & 2011 & 2012 & 2013 & 2014 & 2015 & 2016 & 2017 & 2018 \\
\hline \multirow{2}{*}{137 countries } & 1.007 & 0.993 & 0.994 & 0.988 & 0.994 & 0.994 & 1.048 & 1.008 & 0.998 & 1.000 & 1.012 & 1.003 \\
\hline & \multicolumn{4}{|c|}{0.996} & \multicolumn{4}{|c|}{1.011} & \multicolumn{4}{|c|}{1.003} \\
\hline \multirow{2}{*}{$\begin{array}{c}2^{\text {nd }} \text { stage } \\
(45 \text { countries })\end{array}$} & 0.967 & 0.959 & 0.957 & 0.956 & 0.968 & 0.967 & 0.973 & 0.971 & 0.982 & 0.984 & 0.973 & 0.976 \\
\hline & \multicolumn{4}{|c|}{0.960} & \multicolumn{4}{|c|}{0.970} & \multicolumn{4}{|c|}{0.979} \\
\hline
\end{tabular}

Source: Compiled by the author based on the calculation in DEA Frontier, 2019

Broader aspects enter into the overall evaluation of economics, and these aspects are unnoticeable for DEA, i.e., part of the qualitative assessment in line with the overall performance evaluation. As countries move along the path of growth, their socio-economic conditions change and different determinants become more critical for the macroeconomic competitiveness, as subsequently explained by $\mathrm{WEF}^{48}$ The best way to improve the competitiveness of more developed countries will not necessarily coincide with the idea to enhance less developed countries. Development potentials or weakness are inherent in the national diversity that characterises a sample of all 137 evaluated WTO members. Part of the explanation of efficiency has to do with differences in competitiveness. An economic entity in the country with a low level of competitiveness may not 
have similar opportunities as an economic entity in a highly competitive country. What does it mean for efficiency? In the article, DEA efficiency results differ from GCI results in competitiveness. Why? Is a high level of competitiveness necessarily associated with a high level of efficiency and vice versa? It may not always be the case of evaluated countries based on the classification to the stage of development. In GCR, a country can achieve lower GCI score, and in DEA higher score of efficiency or super-efficiency and seems to operate more efficiently in the reference period. Such a conclusion is relevant by comparing values/quantity of inputs and outputs in DEA. If the input-output ratio is low on both sides, countries could be considered efficient in the transformation process. Such results are not linked with overall competitiveness evaluation, which does not depend primarily on 'efficiency,' but 'effectiveness' (Figure 1).

In Table 4, countries are classified by their belonging to the critical stage of development, i.e., the $2^{\text {nd }}$ efficiency-driven stage, 45 countries are evaluated within the sample. In the first step, the OO BCC VRS model of efficiency was calculated for all stages of development and countries were divided into two groups efficient and inefficient. Based on the chosen model and the relationship between the number of units and the number of inputs and outputs, several efficient units can be relatively large. Due to the possibility of efficient units' classification and ranking from the best to the worst, in the second step, OO APM VRS model of super-efficiency was calculated for all stages of development and countries were divided into efficient and inefficient group. Based on OO BCC VRS scores for group of 45 countries within the $2^{\text {nd }}$ stage of development, overall 2007-18 efficiency ranges from 1.000 - the $1^{\text {st }}$ position (for 18 countries, i.e., Brazil, China, Dominican Republic, Egypt, Guatemala, Indonesia, Jamaica, Namibia, Paraguay, Peru, South Africa, Sri Lanka, Thailand, Argentina, Chile, Costa Rica, Malaysia and Mexico) to 1.122 - the last $27^{\text {th }}$ position (Uruguay), i.e., totally 27 countries recorded inefficient place (El Salvador, Bulgaria, Georgia, Armenia, Panama, Albania, Slovakia, Mauritius, Latvia, Colombia, Turkey, Hungary, Poland, Romania, Montenegro, Morocco, Barbados, Ecuador, Oman, Jordan, Macedonia ("FYR"), Cape Verde, Saudi Arabia, Lithuania, Tunisia, Croatia and Uruguay). In the second step, a model of super-efficiency was calculated. Based OO APM VRS scores for a group of 45 countries within the $2^{\text {nd }}$ stage of development, overall 2007-2018 efficiency ranges from $0.761-$ the $1^{\text {st }}$ position (China) to 1.122 
- the last $42^{\text {nd }}$ position (Uruguay). Totally 30 countries recorded efficient place, i.e., China, Argentina, Sri Lanka, Brazil, Malaysia, Guatemala, Chile, Egypt, Indonesia, Mexico, Peru, Georgia, Dominican Republic, Costa Rica, Jamaica, Armenia, Thailand, El Salvador, Colombia, Ecuador, Barbados, Bulgaria, Panama, Jordan, Slovakia, Albania, Latvia, Mauritius, Poland and Hungary. Within the whole sample of 45 countries, only 12 countries placed at inefficient positions (Romania, Montenegro, Turkey, Morocco, Saudi Arabia, Oman, Macedonia (FYR), Lithuania, Cape Verde, Tunisia, Croatia and Uruguay). Only three countries, Namibia, Paraguay and South Africa, were identified as outliers in the infeasible coefficient of super-efficiency about production possibility frontier.

Table 4: OO BCC-APM VRS Results for $2^{\text {nd }}$ Stage of Development (45 Efficiency-Driven Countries)

\begin{tabular}{|c|c|c|c|c|c|c|c|c|c|}
\hline \multicolumn{5}{|c|}{ OO BCC VRS* } & \multicolumn{5}{|c|}{ OO APM VRS* } \\
\hline Rank & DMU & Country & Score & Category & Rank & DMU & Country & Score & Category \\
\hline \multirow{18}{*}{1} & BRA & Brazil & 1.000 & \multirow{18}{*}{ Efficient } & 1 & $\mathrm{CHN}$ & China & 0.761 & \multirow{18}{*}{ Efficient } \\
\hline & $\mathrm{CHN}$ & China & 1.000 & & 2 & $\mathrm{ARG}$ & Argentina & 0.808 & \\
\hline & DOM & $\begin{array}{l}\text { Dominican } \\
\text { Republic }\end{array}$ & 1.000 & & 3 & LKA & Sri Lanka & 0.853 & \\
\hline & EGY & Egypt & 1.000 & & 4 & BRA & Brazil & 0.856 & \\
\hline & GTM & Guatemala & 1.000 & & 5 & MYS & Malaysia & 0.868 & \\
\hline & IDN & Indonesia & 1.000 & & 6 & GTM & Guatemala & 0.868 & \\
\hline & JAM & Jamaica & 1.000 & & 7 & $\mathrm{CHL}$ & Chile & 0.877 & \\
\hline & NAM & Namibia & 1.000 & & 8 & EGY & Egypt & 0.881 & \\
\hline & PRY & Paraguay & 1.000 & & 9 & IDN & Indonesia & 0.889 & \\
\hline & PER & Peru & 1.000 & & 10 & MEX & Mexico & 0.924 & \\
\hline & $\mathrm{ZAF}$ & South Africa & 1.000 & & 11 & PER & Peru & 0.926 & \\
\hline & LKA & Sri Lanka & 1.000 & & 12 & GEO & Georgia & 0.929 & \\
\hline & THA & Thailand & 1.000 & & 13 & DOM & $\begin{array}{c}\text { Dominican } \\
\text { Republic }\end{array}$ & 0.936 & \\
\hline & $\mathrm{ARG}$ & Argentina & 1.000 & & 14 & CRI & Costa Rica & 0.944 & \\
\hline & $\mathrm{CHL}$ & Chile & 1.000 & & 15 & JAM & Jamaica & 0.945 & \\
\hline & CRI & Costa Rica & 1.000 & & 16 & ARM & Armenia & 0.959 & \\
\hline & MYS & Malaysia & 1.000 & & 17 & THA & Thailand & 0.962 & \\
\hline & MEX & Mexico & 1.000 & & 18 & SLV & El Salvador & 0.962 & \\
\hline
\end{tabular}




\begin{tabular}{|c|c|c|c|c|c|c|c|c|c|}
\hline \multirow{2}{*}{2} & SLV & El Salvador & 1.000 & \multirow{27}{*}{ Inefficient } & 19 & $\mathrm{COL}$ & Colombia & 0.970 & \multirow{12}{*}{ Efficient } \\
\hline & BGR & Bulgaria & 1.000 & & 20 & ECU & Ecuador & 0.971 & \\
\hline 3 & GEO & Georgia & 1.001 & & 21 & BRB & Barbados & 0.973 & \\
\hline 4 & ARM & Armenia & 1.002 & & 22 & BGR & Bulgaria & 0.975 & \\
\hline 5 & PAN & Panama & 1.003 & & 23 & PAN & Panama & 0.981 & \\
\hline 6 & ALB & Albania & 1.005 & & 24 & JOR & Jordan & 0.986 & \\
\hline 7 & SVK & Slovakia & 1.005 & & 25 & SVK & Slovakia & 0.987 & \\
\hline 8 & MUS & Mauritius & 1.006 & & 26 & ALB & Albania & 0.989 & \\
\hline 9 & LVA & Latvia & 1.007 & & 27 & LVA & Latvia & 0.993 & \\
\hline 10 & $\mathrm{COL}$ & Colombia & 1.008 & & 28 & MUS & Mauritius & 0.996 & \\
\hline 11 & TUR & Turkey & 1.009 & & 29 & POL & Poland & 0.997 & \\
\hline 12 & HUN & Hungary & 1.009 & & 30 & HUN & Hungary & 0.998 & \\
\hline 13 & POL & Poland & 1.010 & & 31 & ROU & Romania & 1.000 & \multirow{12}{*}{ Inefficient } \\
\hline 14 & ROU & Romania & 1.012 & & 32 & MNE & Montenegro & 1.001 & \\
\hline 15 & MNE & Montenegro & 1.016 & & 33 & TUR & Turkey & 1.002 & \\
\hline 16 & MAR & Morocco & 1.016 & & 34 & MAR & Morocco & 1.010 & \\
\hline 17 & BRB & Barbados & 1.018 & & 35 & SAU & Saudi Arabia & 1.016 & \\
\hline 18 & ECU & Ecuador & 1.019 & & 36 & OMN & Oman & 1.017 & \\
\hline 19 & $\mathrm{OMN}$ & Oman & 1.023 & & 37 & MKD & $\begin{array}{l}\text { Macedonia, } \\
\text { FYR }\end{array}$ & 1.020 & \\
\hline 20 & JOR & Jordan & 1.024 & & 38 & LTU & Lithuania & 1.031 & \\
\hline 21 & MKD & $\begin{array}{l}\text { Macedonia, } \\
\text { FYR }\end{array}$ & 1.026 & & 39 & $\mathrm{CPV}$ & Cape Verde & 1.034 & \\
\hline 22 & $\mathrm{CPV}$ & Cape Verde & 1.026 & & 40 & TUN & Tunisia & 1.056 & \\
\hline 23 & SAU & Saudi Arabia & 1.028 & & 41 & HRV & Croatia & 1.082 & \\
\hline 24 & LTU & Lithuania & 1.031 & & 42 & URY & Uruguay & 1.122 & \\
\hline 25 & TUN & Tunisia & 1.057 & & 1 & NAM & Namibia & infeasible & I \\
\hline 26 & HRV & Croatia & 1.082 & & 1 & PRY & Paraguay & infeasible & l \\
\hline 27 & URY & Uruguay & 1.122 & & 1 & ZAF & South Africa & infeasible & 1 \\
\hline \multicolumn{3}{|c|}{ Average per group } & 1.013 & 1 & \multicolumn{3}{|c|}{ Average per group } & 0.961 & I \\
\hline
\end{tabular}

Note: Scores based on a national average across years of reference period 2007-2018

Source: Compiled by the authors based on the calculation in of DEA Frontier, 2019 


\section{Chinese Interaction}

The rapid emergence of China as a world trade power has raised concerns in developed and developing economies alike over its potential impact on the world market. China's increasing integration with the global economy has contributed to sustained growth in international trade. Its exports have become more diversified, and greater penetration of industrial country markets has been accompanied by a surge in China's imports from all regions - especially Asia, where China plays an increasingly central role in the regional specialisation. Tariff reforms have been implemented in China since the 1980s; and, with its WTO accession, China has committed itself to additional changes, that are farreaching and challenging. Sustained implementation of these commitments would further deepen China's international integration and generate benefits for most partner countries. ${ }^{49} \mathrm{To}$ fulfil the membership requirements of the WTO, China has to implement its commitment to adopt broad and deep trade liberalisation measures to bring its trade regime consistent with the WTO rules. Implementation of liberalisation measures implies a substantial reduction in tariffs and non-tariff barriers across all economic sectors in one of the world's largest and most rapidly expanding markets. It will not only change China's resource allocation among its domestic production and export sectors, but will also affect the structure of China's trade with its trade partners and their production will have to be adjusted to accommodate such changes. ${ }^{50}$

So, what are the implications of China's incorporation into the world market as well as global trade for competitiveness of other WTO members? As China's trade with the rest of the world has expanded, its composition and geographical pattern have also shifted. Its overall share of exports to industrial economies has increased and become more diversified. China has also become increasingly important in the Asian regional economy. The vertical specialisation of production in Asia has led to an increasing share of China's imports coming from the region, and China is now among the most important export destinations for other Asian countries. Trade reforms and commitments made as part of China's accession to the WTO have been crucial in promoting its integration with the global trading system. Continued implementation of the WTO commitments in the coming years will further facilitate China's ongoing integration in the global economy 
and generate benefits for most partners. It may also pose significant challenges for the authorities; the extensive safeguard provisions under the WTO agreement represent a risk that could constrain China's export growth in the future.

In the past decade, the WTO has decided over forty disputes between China and other powerful economies. These cases are often trumpeted as a sign of the enduring strength of the trade regime and the efficacy of international law in managing geopolitical tensions associated with China's rise. This positive assessment obfuscates the dangers lurking on the horizon. Nowadays, China presents a significant challenge to the multilateral trade regime. At the heart of this challenge is the fact that China's economic structure is sui generis, having evolved in a manner mostly unforeseen by those negotiating WTO treaty law. As a result, the WTO can deal effectively with only a limited range of disputes - those in which Chinese policies largely resemble elements of other alternative economic structures. Outside of this set of issues, the WTO faces two very different but equally serious challenges. The first is to reinterpret certain legal concepts to adapt and fit an unforeseen Chinese context. The second is to decide whether to expand the scope of its legal rules to accommodate issues that currently fall outside of its jurisdiction. The most likely outcome is one in which China's rise will exacerbate the diminishing centrality of the WTO law for global trade governance. ${ }^{52}$

\section{A. Position of Chinese Economy - International Comparison}

Evaluation of the WTO competitiveness was processed in the previous part. What are the impacts on the Chinese economy, however? Based on the empirical results above, at lower levels of development, economic growth is determined primarily by the mobilisation of primary factors of production: land, primary commodities, and unskilled labour. As economies move from low- to middle-income status, competitiveness becomes Investment-driven (instead of Factor-driven), as economic growth is increasingly achieved by harnessing global technologies to local production. Foreign direct investment, joint ventures, and outsourcing arrangements help to integrate the national economy into international production systems, thereby facilitating the improvement of technologies and the inflows of foreign capital and technologies that support economic growth. In most economies, the evolution from middle-income to high-income status involves the transition from a technology-importing economy to a technology-generating economy, one 
that innovates in at least some sectors at the global technological frontier. For high-income economies at this Innovation-driven stage of economic development, global competitiveness is critically linked to high rates of social learning and rapid ability to shift to the new technologies. The principal factors contributing to competitiveness will differ for economies at different levels of development. For some low-income economies, the main challenge is to get the basic factor markets - for land, labour, and capital - working properly. As countries advance, the basic challenge is to make connections with international production systems by attracting sufficient flows of foreign direct investment. Once reaching high-income status, the basic challenge facing countries is to generate high rates of innovation and commercialisation of new technologies.

Related to the analysis of countries based on the stage of development, China belongs to the 2 nd group of countries, i.e., Investment-driven stage of economic development relevant for efficiency-driven economies. Economies at this stage concentrate on manufacturing and outsourced service exports. They achieve higher wages, but are susceptible to financial crises and external, sector-specific demand shocks. This stage implies efforts of upgrading the nation's industry as companies invest in modern technology and more efficient facilities. These aspects are also crucial for orientation of the Chinese economy. Since the reform process started and opening-up policy was adopted in China, the country has experienced a sharp increase in not only its growth rate, but also its trade compared to the rest of the world. China has successfully converted itself from a state with protectionist trade policies to an outward-oriented one with an open economy. During this transition, its trade relations with the rest of the world went through various stages, from isolation and dependence on the Soviet economy to openness. ${ }^{54}$

Its accession to the WTO was an essential step allowing China to participate in world trade within a multilateral trade system. Nearly two decades have passed since China's full opening-up was marked by its accession to the WTO in 2001. As with virtually everything to do with contemporary China, things have changed so much and so quickly since 1978 that it is almost as if we are talking about two different places. It is probably fair to say that we are dealing with two entirely different economies in that the 1978 version had little that we would recognise in the 2008 incarnation, the milestone year for changes in the world economy due to the economic crises. 
While change in the domestic arena has done much to generate this change, engaging the global economy has also played its part in changing China - and in the process also improve the global economy. China's economic rise presages a fundamental change in the global economic and political system. China's integration into the global economy has been one of the main drivers of its economic growth. A particularly significant contribution to GDP and employment growth has been made by some of its industries with comparative advantages and an increasing specialisation level. In recent years, China has pursued exportoriented economic policies and become a prominent trader in world markets and the biggest economy after the US and Japan. International trade has also helped improve the productivity of some domestic industries and led to faster technological progress. In particular, massive imports of capital and intermediate goods have had a significant effect on productivity through the technology incorporated in them; "learning by doing" has also played a key role. ${ }^{55}$ China's partners in the world economy are already benefitting, and stand to benefit more over the coming decades, from the economic impact of growth on a scale unprecedented in history. ${ }^{56}$

Both the scale and the character of China's economic and social development mean that there will be powerful feedback effects as the rest of the world adjusts to China's presence in all aspects of global economic and political life affecting Chinese policies and systems, as well as behaviour in other countries towards China. Larger countries are likely to take an active position in managing their economic and political interests as they are affected by the impact of developments in China on the structure of international markets. This is not just a matter of the scale of China's growth and its role in the world, although the range is certainly one dimension. Within less than a few decades, China has transformed itself from being a 'small' economy to being a 'big' economy in terms of its impact on world trade and output, world prices, its role in international capital flows and financial markets, its effect on the global commons and its stake in managing the international economic and political system. These changes have seen China seek to conform to established international norms and institutions; to exercise responsibility within the G20 in managing the global economic system; and to play an increasingly active and constructive role in international diplomacy. ${ }^{57}$

China's emergence as the world's second-largest single trader in the world 
economy has been managed successfully in the global system of trade rules and institutions. As Chinese business goes abroad, there are more complex interactions between the market and the state. Despite the scale of these changes and China's increasingly important role in the world, China's economy is still in transition, with wide-ranging reforms even in progress. This affects how the market operates across all sectors of the economy. China has a political system that is different from the broadly representative ones that typify the established international powers. Economic transition in China has had and is continuing to have a significant impact on the political system and how the political system operates within China. There is a question of whether continuing economic reform might lead inevitably to a trend towards further political system change because of the need for a separation of the state from the economic enterprise, to facilitate the governance and transparency necessary to achieve very high levels of prosperity. The relationship between the efficiency of economic institutions and the nature of the political institutions in which they are nested is one crucial question.

In terms of international relations, of more practical importance is the development of an understanding of the way in which Chinese markets and business are affected by evolving economic and political institutions. It is important to look further how participants in these markets interact with the state in their dealings in international markets, and whether the relationship between the market and political system requires particular strategic policy responses from China's economic partners. The relationship between the efficiency of economic institutions and the nature of the political institutions in which they are nested is one important question. There is a question of whether continuing economic reform might lead to facilitate the governance and transparency necessary to achieve very high levels of prosperity. ${ }^{58}$

Related to China's economic partners, within the article, the country was compared with the other WTO members as a whole (Table 3), as well as with countries in the same group of the $2^{\text {nd }}$ stage of development, i.e., Investmentdriven economies (Table 4), both in the reference period 2007-2018. Table 5 shows China results obtained in comparison with 137 countries, i.e., in the sample of all evaluated countries as a whole, both for efficiency and super-efficiency models in all individual years of reference period as well as for national average across all years of reference period 2007-2018. In a comparison of 137 countries, 
based on OO APM VRS model of super-efficiency, China gets score 0.905 overall efficiencies for 2007-2018. In a comparison of all reference years, minimum super-efficiency score 0.817 was recorded in 2007 , the best result concerning the orientation of OO APM VRS model of super-efficiency. Maximum superefficiency score 0.968 was recorded in 2013, the worst result concerning the orientation of OO APM VRS model of super-efficiency.

Table 5: OO BCC-APM VRS Scores of China (137 Countries)

\begin{tabular}{|c|c|c|c|c|c|c|c|c|c|c|c|c|c|}
\hline DMU & \multicolumn{12}{|c|}{ OO BCC VRS Model of Efficiency } & $\begin{array}{c}\text { Overall } \\
\text { Efficiency* }\end{array}$ \\
\hline \multirow{7}{*}{$\begin{array}{l}\text { China } \\
\text { CHN }\end{array}$} & 2007 & 2008 & 2009 & 2010 & 2011 & 2012 & 2013 & 2014 & 2015 & 2016 & 2017 & 2018 & $\begin{array}{l}\text { OO BCC } \\
\text { VRS }\end{array}$ \\
\hline & 1.000 & 1.000 & 1.000 & 1.000 & 1.000 & 1.000 & 1.000 & 1.000 & 1.000 & 1.000 & 1.000 & 1.000 & 1.000 \\
\hline & \multicolumn{12}{|c|}{ OO APM VRS Model of Super-Efficiency } & $\begin{array}{c}\text { Overall } \\
\text { Efficiency* }\end{array}$ \\
\hline & 2007 & 2008 & 2009 & 2010 & 2011 & 2012 & 2013 & 2014 & 2015 & 2016 & 2017 & 2018 & $\begin{array}{l}\text { OO APM } \\
\text { VRS }\end{array}$ \\
\hline & 0.817 & 0.884 & 0.894 & 0.854 & 0.909 & 0.920 & 0.968 & 0.927 & 0.929 & 0.916 & 0.916 & 0.921 & 0.905 \\
\hline & \multicolumn{4}{|c|}{$\begin{array}{c}\text { Minimum } \\
\text { (the best result) }\end{array}$} & \multicolumn{8}{|c|}{0.817} & 2007 \\
\hline & \multicolumn{4}{|c|}{$\begin{array}{c}\text { Maximum } \\
\text { (the worst results) }\end{array}$} & \multicolumn{8}{|c|}{0.968} & 2013 \\
\hline
\end{tabular}

Note: Scores based on a national average across years of reference period 2007-2018

Source: Compiled by the authors based on the calculation in DEA Frontier, 2019

Figure 2 shows the evolution of Chinese super-efficiency scores in all individual years within reference period 2007-2018, as well as increasing and decreasing trend scores over the entire period with maximum and minimum values, i.e., the best ( 0.817 obtained in 2007$)$ and worst ( 0.968 obtained in 2013$)$ ratings. 
Figure 2: Evolution of Chinese Super-Efficiency in 2007-2018 (137 Countries)

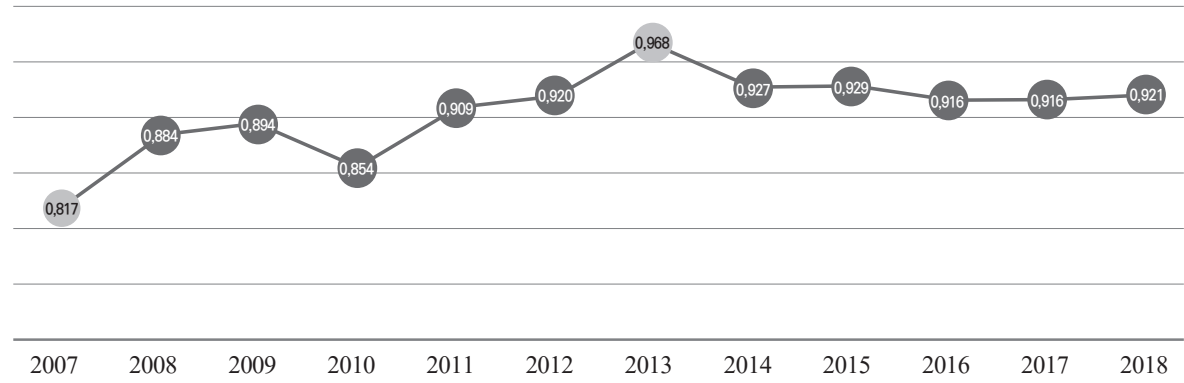

Source: Compiled by the authors based on the calculation in DEA Frontier, 2019

Table 6 shows China results obtained in the comparison of countries within the $2^{\text {nd }}$ stage of development, i.e., Investment-driven economies, both for efficiency and super-efficiency models in all individual years of reference period as well as for national average across all years of reference period 2007-2018. In a comparison of 45 countries, based on OO APM VRS model of super-efficiency, China gets score 0.761 overall efficiencies for 2007-2018 and placed at $1^{\text {st }}$ position. In a comparison of all reference years, minimum super-efficiency score 0.684 was recorded in 2011, the best result concerning the orientation of OO APM VRS model of super-efficiency. Maximum super-efficiency score 0.818 was recorded in 2017, the worst result concerning the orientation of OO APM VRS model of super-efficiency. 
Table 6: OO BCC-APM VRS Scores of China (45 Countries)

\begin{tabular}{|c|c|c|c|c|c|c|c|c|c|c|c|c|c|}
\hline DMU & \multicolumn{12}{|c|}{ OO BCC VRS Model of Efficiency } & $\begin{array}{c}\text { Overall } \\
\text { Efficiency* }\end{array}$ \\
\hline \multirow{7}{*}{$\begin{array}{l}\text { China } \\
\text { CHN }\end{array}$} & 2007 & 2008 & 2009 & 2010 & 2011 & 2012 & 2013 & 2014 & 2015 & 2016 & 2017 & 2018 & $\begin{array}{l}\text { OO BCC } \\
\text { VRS }\end{array}$ \\
\hline & 1.000 & 1.000 & 1.000 & 1.000 & 1.000 & 1.000 & 1.000 & 1.000 & 1.000 & 1.000 & 1.000 & 1.000 & 1.000 \\
\hline & \multicolumn{12}{|c|}{ OO APM VRS Model of Super-Efficiency } & $\begin{array}{c}\text { Overall } \\
\text { Efficiency* }\end{array}$ \\
\hline & 2007 & 2008 & 2009 & 2010 & 2011 & 2012 & 2013 & 2014 & 2015 & 2016 & 2017 & 2018 & $\begin{array}{l}\text { OO APM } \\
\text { VRS }\end{array}$ \\
\hline & 0.714 & 0.801 & 0.758 & 0.761 & 0.684 & 0.735 & 0.758 & 0.734 & 0.760 & 0.815 & 0.818 & 0.798 & 0.761 \\
\hline & \multicolumn{4}{|c|}{$\begin{array}{c}\text { Minimum } \\
\text { (the best result) }\end{array}$} & \multicolumn{8}{|c|}{0.684} & 2011 \\
\hline & \multicolumn{4}{|c|}{$\begin{array}{c}\text { Maximum } \\
\text { (the worst result) }\end{array}$} & \multicolumn{8}{|c|}{0.818} & 2017 \\
\hline
\end{tabular}

Note: Scores based on a national average across years of reference period 2007-2018

Source: Compiled by the authors based on the calculation in DEA Frontier, 2019

Figure 3 shows the evolution of Chinese super-efficiency scores in all individual years within reference period 2007-2018, as well as increasing and decreasing trend scores over the entire period with maximum and minimum values, i.e., the best ( 0.684 obtained in 2011$)$ and worst ( 0.818 obtained in 2017$)$ ratings.

Figure 3: Evolution of Chinese Super-Efficiency in 2007-18 (45 Countries)

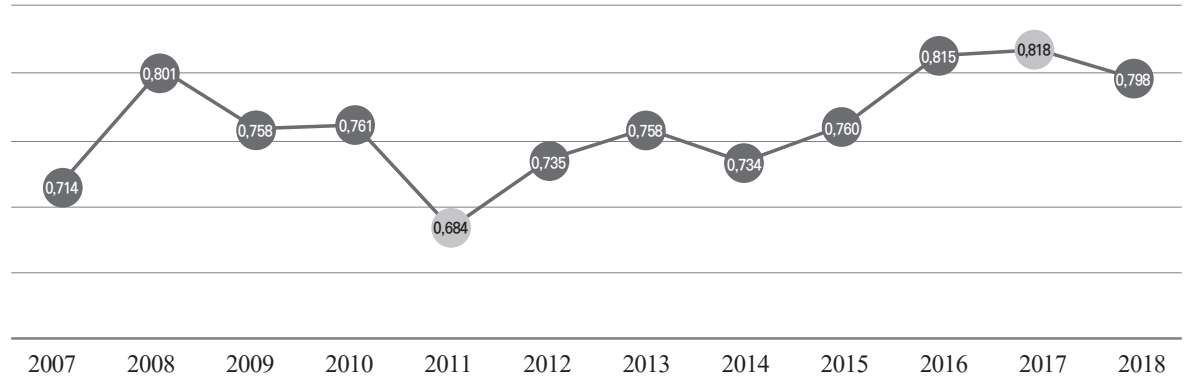

Source: Compiled by the authors based on the calculation in DEA Frontier, 2019 


\section{B. Pros and Cons of the Chinese Economy}

As mentioned above, the 2008 global financial crisis interrupted a period of sustained economic growth dating back to the 1960s. Since then, despite unorthodox monetary policy and fiscal stimulus packages, advanced economies have experienced prolonged comparatively sluggish growth. In emerging markets, the impact of the global financial crisis was lessened in part by interest rate differentials, with advanced economies fuelling capital inflows in the form of foreign direct investment, the super commodity boom, and the rapid growth of China. China has come a long way since 1978 when Deng Xiaoping heralded a new era of market-oriented reforms. In 1978, China started the historic process of reform and opening-up. This is a glorious part in the development epic of the country and the nation composed by the Chinese people, recording the great journey of the common progress of China and the rest of the world. It has not only profoundly changed the country, but also greatly influenced the whole world. From 1980 to 2010, its economy grew 18 -fold, averaging 10 percent a year. It progressed from low-income to upper-middle-income country status, lifting hundreds of millions out of poverty: by 2011 just 6 percent of people were in extreme poverty, compared with 61 percent in $1990 .{ }^{59}$ Opening-up was crucial for China's economic growth over the past 40 years. In the same vein, high-quality development of China's economy in the future can only be achieved with greater openness. $^{60}$

Recent developments - including the weakening of CNY/RMB, the stock market crash, rapid credit growth, and a stalling property market - have cast some doubt on China's economic prospects. A hard landing of the Chinese economy still seems unlikely, for three reasons. First, as the GCI shows, China possesses strong economic foundations. The country ranks $27^{\text {th }}$ out of 137 economies in the 20172018 edition. ${ }^{61}$ China has achieved near-universal primary education, and high levels of public health, invested massively in transport and energy infrastructure and ensured a relatively stable macroeconomic environment. These successes have not only contributed to China's emergence as a manufacturing hub, but also represented assets on which to build on. China's advantages are not shared by many neighbouring economies at a similar stage of development, as shown in Figure 4. 
Figure 4: China in $12 \mathrm{GCI}$ Pillars (Score 1-7) ${ }^{62}$

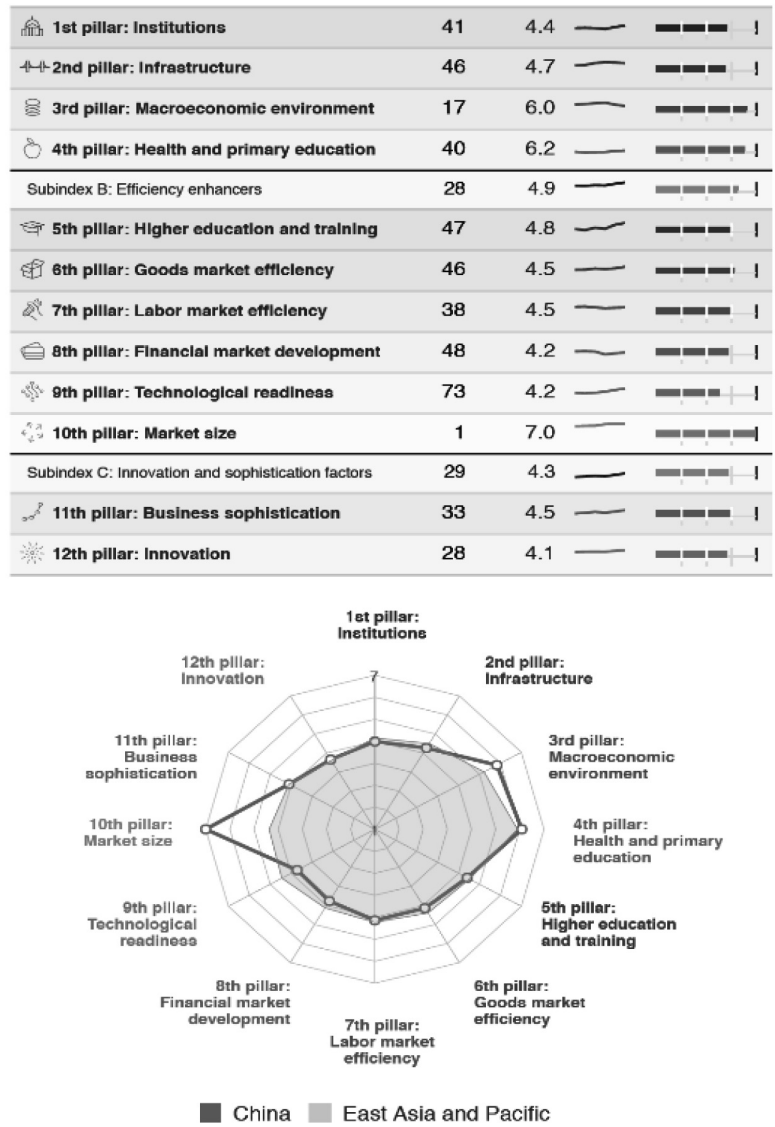

China $\left(27^{\text {th }}\right.$ position) has gained one place as a result of steady, albeit incremental, improvements to its overall competitiveness score. Since 2018, China has made progress in all pillars except macroeconomic environment and infrastructure. The aforementioned decline is explained by a worsening of the government budget deficit. $^{63}$ The score for the infrastructure decreases for the second year in a row, the result in part of a decline in the quality of port infrastructure and the reliability of electricity supply as perceived by the business community. The most significant gains are observed in technological readiness, owing to higher ICT penetration and the extent to which foreign direct investments have been bringing new technologies to China. ${ }^{64}$ 
Despite the remarkable progress already made, further improvement would foster the growth of emerging digital industries and create the conditions necessary to kick-start new ones. Other advances have been made in the goods market efficiency pillar as a result of a slight reduction in the number of procedures for business starting compared to last year. An eventual slowdown was inevitable, predictable, and entirely reasonable, given China's impressive growth trajectory over the past two decades. WEF compares China's annual real growth rate from 1980 to the GDP-weighted average growth rate of other countries in the income group to which it belonged in each year. Since 1991, China has grown faster than its peers every year. For several years in the 1990s, the differential was almost ten percentage points. Since achieving upper-middle-income status in 2010, the differential has been around 5 percentage points. ${ }^{65}$ Third, even though it has not yet abandoned the official 7 percent target, there are signs that the government has been preparing for the economy's new phase and has been recalibrating its growth objectives from the quantitative to the qualitative. The $12^{\text {th }}$ five-year plan, adopted in 2011 and covering 2010-2015, had called for a rebalancing of the economy. President Xi referred to a "new normal" under which growth will be lower. ${ }^{66}$

Even though the economy is unlikely to experience a hard landing, there are many challenges and downside risks. Under the new standard, productivity gains will be harder to achieve. This is reflected in China's stagnation in GCI rankings for the past four years. ${ }^{67}$ The drivers that fuelled China's growth - investment, low wages, urbanisation - are yielding diminishing returns or even vanishing. Future gains will have to come through more market-oriented reforms that tackle remaining distortions, controls, and rigidities across the economy and that enable more efficient use of factors of production. The list of the most problematic factors for doing business in China is topped by its lack of capacity to innovate, which has become a growing concern in recent years (Figure 5). Evolving from a manufacturing-based economy to an innovation powerhouse for design and $\mathrm{R} \& \mathrm{D}$ requires a holistic approach to the innovation ecosystem, including nurturing talent (China ranks $47^{\text {th }}$ in higher education and training) and technological readiness (China ranks $73^{\text {rd }}$ ). 
Figure 5: Most Problematic Factors for Doing Business in China ${ }^{68}$

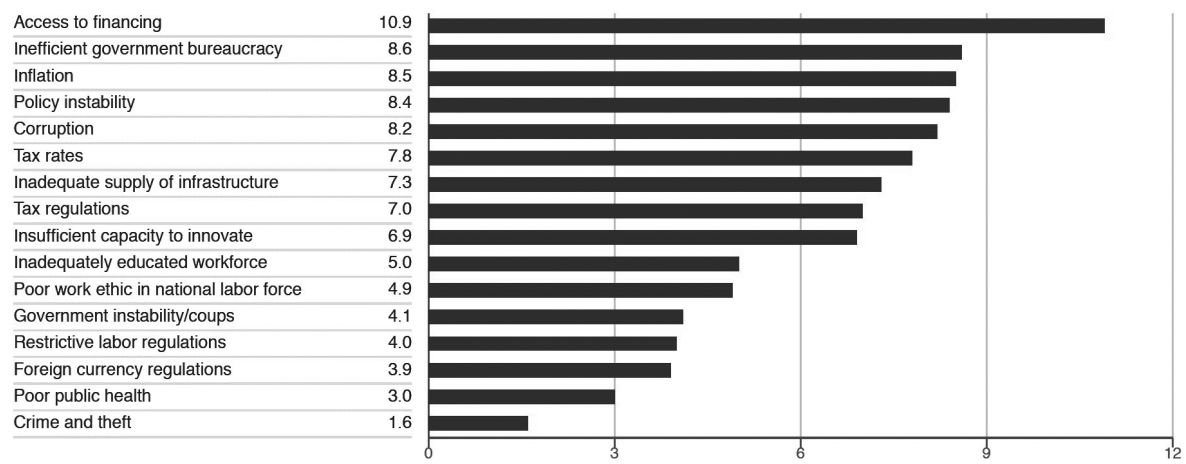

\section{Demands of the New Economy - the Fourth Industrial Revolution}

Klaus Schwab said:

Embracing the Fourth Industrial Revolution has become a defining factor for competitiveness. With this report, the World Economic Forum proposes an approach to assess how well countries are performing against this new criterion. I foresee a new global divide between countries who understand innovative transformations and those that don't. Only those economies that recognise the importance of the Fourth Industrial Revolution will be able to expand opportunities for their people. ${ }^{69}$

WEF's Global Competitiveness Report 2018 and its GCI 4.0 uses a brand new methodology to fully capture the dynamics of the worldwide economy in the 4IR. GCI 4.0 uses many of the factors that will have the most significant impact in driving competitiveness in the future. ${ }^{70}$

These include idea generation, entrepreneurial culture, openness, and agility. The new tool maps the competitiveness landscape of 140 economies through 98 indicators organised into 12 pillars, i.e., main drivers of productivity (Institutions, Infrastructure, Technological readiness, Macroeconomic context, Health, Education and skills, Product market, Labor market, Financial system, Market size, Business dynamism, and Innovation). For each indicator, using a scale from 0 to 100 , it indicates how close an economy is to the ideal state or 'frontier' of competitiveness, the perfect state, where a country would obtain the perfect score on every component of the index. The average score for the world is 60,40 points away from the frontier. When combining these factors, the United States achieves 
the best overall performance with a score of 85.6. It is followed by Singapore (83.5) and Germany (82.8). Switzerland (82.6) comes in at $4^{\text {th }}$ place, followed by Japan (82.5), The Netherlands (82.4), Hong Kong SAR (82.3). The UK (82.0), Sweden (81.7) and Denmark (80.6) round out the top ten. Globalisation has contributed to reducing both global poverty and between-countries inequality. Trade has committed to generating prosperity across all countries in the past few decades. The benefits of trade openness have been particularly remarkable in South-East Asia and China, where export-led economic growth has quickly raised the living standards of a sizable portion of the population. China ranks $28^{\text {th }}$ overall (score of 72.6), leading the BRICS economies ahead of the Russian Federation $\left(65.6,43^{\text {rd }}\right)$, India $\left(62.0,58^{\text {th }}\right)$, South Africa $\left(60.8,67^{\text {th }}\right)$ and Brazil $\left(59.5,72^{\text {nd }}\right) .{ }^{71}$

As the world's second-largest economy, China is now at a critical juncture as it transitions to a new phase of its economic development - referred to as the "new normal" by President Xi Jinping - in which its economy is driven less by investments and exports and more by consumption and services. In this context, the country has been increasingly betting on innovation. It has become a prominent player in some specific areas, like artificial intelligence. With a score of $64.4\left(24^{\text {th }}\right)$ it already stands above many advanced economies, but still trails leaders like Germany, the US and Switzerland by some 20 points. To catch up with these "super innovators," China would need to improve performance on softer drivers of innovation, such as diversity, collaboration and various aspects of openness. Other relative strengths include the Infrastructure $\left(78.1,29^{\text {th }}\right)$ and ICT adoption $\left(71.5,26^{\text {th }}\right)$ pillars, two remarkable achievements given the sheer size of the country. On a less positive note, China's institutional framework $\left(54.6,65^{\text {th }}\right)$ needs further improvement. Policy-makers should also offer a more level-playing field for companies by promoting domestic and foreign competition $\left(57.4,55^{\text {th }}\right)$, and addressing various inefficiencies and rigidities in the labour market (59.3, $\left.69^{\text {th }}\right)$, as Figure 6 shows. ${ }^{72}$ 
Figure 6: $\mathrm{GCl} 4.0$ - Performance Overview of China ${ }^{73}$

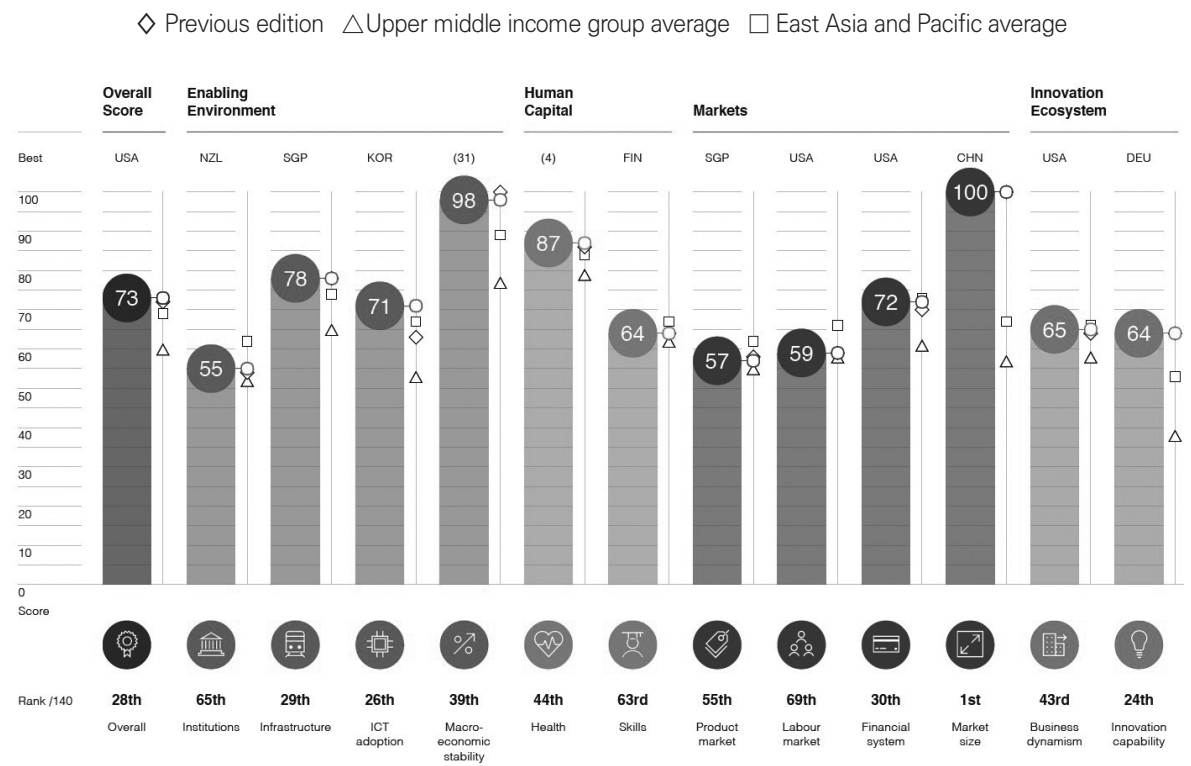

\section{Conclusion}

Globalisation has obliged all countries to raise their standards of economic efficiency. Therefore, the growing interest in and concern about competitiveness: nations, regions and cities have no option but to strive to be competitive in order to survive in the new global marketplace and the "new competition" being forged by the further information or knowledge-driven economy. The evaluation of a country's performance is crucial to the country's efforts to improve its international competitiveness. Strengthening both global openness and domestic competitiveness has never been more critical. Policy-makers at all levels have been swept up in this competitiveness fever, too. This growing interest may perhaps be partly attributable to their awareness of the fact that all countries are having to contend with raised standards of economic efficiency as a result of the globalisation of goods and factor markets. The economy may be competitive, but if the society and the environment suffer too much, the country will face significant difficulties and vice versa. Policies oriented to solve the main economic 
and social problems of their citizens may then not focus only on the improvement of indicators of competitiveness, but also on the reduction of differences in competitiveness compared to other players in the world economy. Differences in competitiveness may explain many of the differences in economic growth and quality of life within a country.

The methodological framework of the article measures macroeconomic competitiveness of the WTO members based on GCI pillars. This article has thus closely followed the methodology proposed by WEF. Determinants of competitiveness - pillars were distinguished into input and output size, which measure different aspects of transformation processes of economic activities. Using efficiency analysis through DEA approach - the method aimed to identify the efficient and inefficient countries of the WTO and to estimate the relative efficiency of each country within the evaluated sample. Does it evolve the question: why measuring macroeconomic competitiveness is essential? William Thomson, $1^{\text {st }}$ Baron Kelvin said:

\footnotetext{
When you can measure what you are speaking about, and express it in numbers, you know something about it, when you cannot express it in numbers, your knowledge is of a meager and unsatisfactory kind; it may be the beginning of knowledge, but you have scarcely, in your thoughts advanced to the stage of science. ${ }^{74}$
}

A quantitative score of competitiveness will facilitate the WTO members in identifying possible weaknesses together with factors mainly driving these weaknesses. In reality, every pillar may not play an equal role in the competitiveness of every country, which is 'logical.' It requires the need for a broad-based approach to raising competitiveness - a strong performance in one area cannot make up for a weak performance in another. This is especially true when it comes to innovation: while it is true that a strong focus on technology can provide leapfrogging opportunities for low and middle-income countries, governments must not lose sight of 'old' developmental issues, such as governance, infrastructure and skills. In this context, WEF introduced GCI 4.0, a muchneeded economic compass, building on 40 years of experience in benchmarking the drivers of longterm competitiveness. After having conceptualised 4IR, WEF is contributing to global thinking and policy-making by integrating the notion of 4IR into the definition of competitiveness. The results of GCI 4.0 reveal the sobering 
conclusion that most economies are far from the competitiveness 'frontier' - the aggregate ideal across all factors of competitiveness. The global average score of 60 suggests that many economies have yet to implement the measures that would enhance their longterm growth and resilience and broaden opportunities for their populations. $^{75}$

The world is undergoing a new round of significant development, meaningful change and profound readjustment. Humanity still faces growing uncertainties and destabilising factors. Surging tides of anti-globalisation in recent years, coupled with rising protectionism and unilateralism, have posed severe challenges to the multilateral trading system with the WTO at its core. Economic globalisation has powered global growth and is an irreversible trend of our times. China and the multilateral trading system stand together through thick and thin. China will have significant challenges to fulfill its commitments, comply with rules, actively participate in the improvement of the multilateral trading system, and give firm support to the WTO in playing a more significant role in global economic governance. $^{76}$

The possible extension of the current research can be oriented on evaluation of peed units of China and analyse the results in terms of optimal or recommended changes in the original inputs and outputs, so that the evaluated unit becomes more effective. This analysis can be made for each year in order to evaluate strengths and weaknesses on input and output side in order to find the best combination to improve the state of the economy. 


\section{REFERENCES}

1. D. Mihaiu \& A. Opreana \& M. Cristescu, Efficiency, effectiveness and performance of the public sector, 1(4) Romanian J. ECON. ForeCASTING. 132-47 (2010), available at http:// www.ipe.ro/rjef/rjef4_10/rjef4_10_10.pdf.

2. WEF, The Global Competitiveness Report 2018, Press Releases (2018), available at http:// reports.weforum.org/global-competitiveness-report-2018/press-release.

3. P. Krugman, Competitiveness: A Dangerous Obsession, 73(2) Foreign AfF. $28-44$ (1994).

4. President's Commission on Industrial Competitiveness, Global Competition: The New Reality. Washington: U.S. Government Printing Office (1985).

5. R. Barrell \& G. Mason \& M. O’Mahony, Productivity, Innovation and Economic Growth 25 (2000).

6. KRUGMAN, supra note 3.

7. M. Starr \& J. Ullman, The Myth of Industrial Supremacy, in Global Competitiveness 54 (M. Starr ed., 1988).

8. L. Tyson, Competitiveness: An Analysis of the Problem and Perspective on Future Policy, in Starr ed., id. at 18.

9. B. Scott \& G. Lodge, US Competitiveness in the World Economy 3 (1985).

10. G. Feketekuty, The Scope, Implication and Economic Rationale of a CompetitionOriented Approach to Future Multilateral Trade Negotiation, 19(1) WorLd ECON. 167-81 (1996).

11. M. Porter, The Competitive Advantage of Nations 22 (1990).

12. L. Fojtíková \& M. Staníčková, How Do the Stages of Economic Development Affect China's Competitiveness? Efficiency Analysis: the Chinese Position as a Global Player in Comparison with the WTO Members, in 42 Progress in EConomics Research 37-100 (2019).

13. M. Farrell, The Measurement of Productivity Efficiency, 120(3) J. Royal Statistical SOC'y 253-90 (1957).

14. W. Cooper \& L. Seiford \& K. Tone, Introduction to Data Envelopment Analysis and its Uses With DEA-solver Software AND ReFERENCEs 45 (2006).

15. WEF, The Global Competitiveness Report 2017-2018 (2017), available at http://www3. weforum.org/docs/GCR2017-2018/05FullReport/TheGlobalCompetitivenessReport2017 $\%$ E2\%80\%932018.pdf.

16. PORTER, supra note 11, at 555-65.

17. M. Porter \& J. SAChS \& J. McArthur, Executive Summary: Competitiveness and Stages of Economic Development 16-25 (2002), available at https://www.earth.columbia.edu/ sitefiles/file/Sachs\%20Writing/2002/WorldEconomicForum_2001-2002_GlobalCompeti tivenessReport2001-2002_ExecutiveSummary.pdf.

18. Mihaiu, Opreana \& Cristescu, supra note 1. 
19. PorTer, supra note 11.

20. P. Drucker, The Efficiency of the Decision Makers 15 (2001).

21. IMD, IMD World Competitiveness Yearbook 28-34 (2012), available at https://www. imd.org/wcc/world-competitiveness-center.

22. Id.

23. Farrell, supra note 13.

24. A. Charnes \& W. Cooper \& E. Rhodes, Measuring the efficiency of decision making units, 2(6) Eur. J. Operation Res. 429-44 (1978).

25. R. Banker \& A. Charnes \& W. Cooper, Some Models for Estimating Technical and Scale Inefficiencies in Data Envelopment Analysis, 30(9) MGMT. ScI. 1078-92 (1984).

26. K. Tone, A slacks-based measure of super-efficiency in data envelopment analysis, 143(1) Eur. J. Operational Res. 32-41 (2002).

27. D. Deprins \& L. Simar \& H. Tulkens, Measuring Labor-Efficiency in Post Offices, in THE Performance of Public Enterprises: Concepts and Measurements 243-67 (1994).

28. W. Cooper \& L. Seiford \& J. Zhu, Data Envelopment Analysis: History, Models and Interpretations, in Handbook on Data Envelopment Analysis 1-40 (2004).

29. COOPER \& SEIFORd \& TONE, supra note 14.

30. Id.

31. P. Andersen \& N. Petersen, A Procedure for Ranking Efficient Units In Data Envelopment Analysis, 3910 Mgmt. Scr. 1261-64 (1993).

32. W. Cooper, \& S. Li \& L.M. Seiford \& J. Zhu, Sensitivity analysis in DEA, in HandBook on Data EnVelopment Analysis 71-92 (2004).

33. WEF, supra note 15 , at 320.

34. L. Melecký, The main achievements of the EU structural funds 2007-2013 in the EU member states: efficiency analysis of transport sector, 13(2) EQUILIBRIUM Q. J. Econ. \& ECON. PoL'y 285-306 (2018).

35. J. Hančlová \& L. Melecký, Application of the Nonparametric DEA Meta-frontier Approach with Undesirable Outputs in the Case of EU Regions, 7(2) Bus. Systems Res. J. 65-77 (2016).

36. WTO, Members and Observers (2016), available at https://www.wto.org/english/thewto_e/ whatis_e/tif_e/org6_e.htm.

37. WEF, supra note $15,320$.

38. WEF, supra note $36,37$.

39. WEF, supra note $15,320$.

40. WEF, Global Competitiveness Index - Competitiveness Rankings (2018a), available at http://reports.weforum.org/global-competitiveness-index/competitiveness-rankings.

41. WEF, Reports (2018b), available at http://reports.weforum.org/global-competitivenessreport-2015-2016/downloads/?doing_wp_cron=1513437847.2438359260559082031250.

42. P. Annoni \& K. Kozovska, EU Regional Competitiveness Index 2010, $27-49$ (2010). 
43. WEF, supra note 15, at 317-9.

44. WEF, The Global Competitiveness Report 2018. Press Releases (2018c), available at http://reports.weforum.org/global-competitiveness-report-2018/press-release.

45. WEF, supra note 44.

46. WEF, supra note 15.

47. Id.

48. WeF, Global Competitiveness Report 2001-2002, 12 (2001).

49. T. Rumbaugh \& N. Blancher, China: International Trade and WTO Accession, IMF Working Paper No. WP/04/36, 1-25 (2004).

50. Z. Wang, The Impact of China's WTO Accession on the World Economy, at 1-18, available at https://www.gtap.agecon.purdue.edu/resources/download/397.pdf.

51. WEF, The Case for Trade and Competitiveness 1-16 (2015), available at http://www3. weforum.org/docs/WEF_GAC_Competitiveness_2105.pdf.

52. M. Wu, The 'China, Inc.' Challenge to Global Trade Governance, 57 Harv. InT'L L. J. 1001-63 (2016).

53. WEF, supra note 51.

54. Wang, supra note 50.

55. M. Ando, Fragmentation and vertical intra-industry trade in East Asia, 17 Nortн Ам. J. ECON. \& Fin. 257-81 (2006).

56. G. Caporale \& A. Sova \& R. Sova, Trade Flows and Trade Specialization: The Case of China, Economics and Finance Working Paper Series Working Paper No. 15-07, 261-73 (2015).

57. P. Drysdale, Politics and Chinese integration into the global economy (2010), at 1 , available at http://www.eastasiaforum.org/2010/04/04/politics-and-chinese-integrationinto-the-global-economy.

58. Drysdale, $i d$.

59. World Bank Group \& World Trade Organization, The Role of Trade in Ending Poverty (2015), available at http://www.worldbank.org/en/topic/trade/publication/the-role-oftradein-ending-poverty.

60. China's State Council Information Office, China and the World Trade Organization (2018), available at http://english.gov.cn/archive/white_paper/2018/06/28/content_ 281476201898696.htm.

61. WEF, supra note 15 , at 90.

62. Id.

63. Id.

64. Id.

65. Id.

66. Id.

67. Id. 
68. Id.

69. WEF, supra note 44.

70. Id.

71. Id.

72. Id. at 27.

73. Id. at 159 .

74. Lecture on "Electrical Units of Measurement" (May 3, 1883), published in Popular Lectures Vol. I, at 7, available at https://archive.org/stream/popularlecturesa01kelvuoft\# page/73/mode/2up.

75. WEF, supra note 44.

76. China's State Council Information Office, supra note 55. 